Cell Research (2003); 13(4):251-263

http://www.cell-research.com

\title{
Embryonic stem cells generated by nuclear transfer of human so- matic nuclei into rabbit oocytes
}

Ying CHEN ${ }^{1,2}$, Zhi Xu HE ${ }^{3}$, Ailian LiU ${ }^{1,2}, \mathrm{Kai} \mathrm{WANG}^{1,2}$, Wen Wei MAO ${ }^{1,2}$, Jian Xin CHU ${ }^{1}$, 2, Yong LU ${ }^{1,2}$, Zheng Fu FANG ${ }^{1,2}$, Ying TANG SHI ${ }^{1,2}$, Qing Zhang YANG ${ }^{1,2}$, Da YuAn CHEN ${ }^{4}$, Min Kang WANG ${ }^{4}$, Jin Song LI ${ }^{4}$, Shao Liang HUANG ${ }^{3}$ ， Xiang Yin KONG ${ }^{5}$, Yao Zhou SHI ${ }^{5}$, Zhi Qiang WANG5, Jia Hui XIA ${ }^{6}$, Zhi Gao LONG ${ }^{6}$, Zhi Gang XUE ${ }^{6}$, Wen Xiang Ding ${ }^{7}$, Hui Zhen $\mathrm{SHENG}^{1},{ }^{2, *}$

${ }^{1}$ Center for Developmental Biology, Shanghai Second Medical University, Shanghai 200092, China

2 Laboratory of Stem Cell Biology, Institute of Biochemistry and Cell Biology, Shanghai Institutes for Biological Sciences, Chinese Academy of Sciences, 1665 Kong Jiang Road, Shanghai 200092, China

${ }^{3}$ Center for Stem Cell Research, the Second Affiliated Hospital, Sun Yat-Sen University, Guangzhou 510120, China

${ }^{4}$ State Key Laboratory of Reproductive Biology, Institute of Zoology, Chinese Academy of Sciences, 19 Zhong-guan Cun Road, Haidian District, Beijing 100080, China

5 Health Science Center, Shanghai Institutes of Biological Sciences, Chinese Academy of Sciences and Shanghai Second Medical University, Shanghai 200025, China

${ }^{6}$ National Laboratory of Medical Genetics, Central South University, 88 Xiangya Road, Changsha 410078, China

7 Xinhua Hospital, Shanghai Second Medical University, 1665 Kong Jiang Road, Shanghai 200092, China

\section{ABSTRACT}

To solve the problem of immune incompatibility, nuclear transplantation has been envisaged as a means to produce cells or tissues for human autologous transplantation. Here we have derived embryonic stem cells by the transfer of human somatic nuclei into rabbit oocytes. The number of blastocysts that developed from the fused nuclear transfer was comparable among nuclear donors at ages of 5, 42, 52 and 60 years, and nuclear transfer (NT) embryonic stem cells (ntES cells) were subsequently derived from each of the four age groups. These results suggest that human somatic nuclei can form ntES cells independent of the age of the donor. The derived ntES cells are human based on karyotype, isogenicity, in situ hybridization, PCR and immunocytochemistry with probes that distinguish between the various species. The ntES cells maintain the capability of sustained growth in an undifferentiated state, and form embryoid bodies, which, on further induction, give rise to cell types such as neuron and muscle, as well as mixed cell populations that express markers representative of all three germ layers. Thus, ntES cells derived from human somatic cells by NT to rabbit eggs retain phenotypes similar to those of conventional human ES cells, including the ability to undergo multilineage cellular differentiation.

Key words: nuclear transfer (NT), somatic cell nuclear transfer (SCNT), embryonic stem cells (ES cell), therapeutic cloning, rabbit oocyte.

* Correspondence: Dr. Hui Zhen SHENG, Center for Developmental Biology, 1665 Kong Jiang Road, Xinhua Hospital, Shanghai Second Medical University, Shanghai, 200092 China. Telephone and fax number: 0086-21-55570017 E-mail: hzsheng@sh163a.sta.net.cn Received Aug-4-2003 Received Aug-11-2003 Accepted Aug-13-2003
Dr. Hui Zhen SHENG is also an adjunct faculty member in the Department of Pharmacology/Cecil H. \&amp; Ida Green Center for Reproductive Biology Sciences, The University of Texas Southwestern Medical Center, Dallas, TX, USA 


\section{INTRODUCTION}

We hypothesized that somatic nuclei from a human patient could be reprogrammed by nuclear transfer (NT) into an oocyte to generate nuclear transfer embryonic stem cells (ntES cells). Cells or tissue derived by this pathway would have nuclear DNA identical to the patient's and, therefore, would likely not be subject to immune rejection[1-3]. In cows and mice, NT technology and ES cell derivation have been used successfully in combination to establish ES or ES-like cell lines from reprogrammed somatic cell nuclei[4-7], and mouse ntES cells have been shown to be fully pluripotent[7].

The approach of nuclear transplantation promises a solution to the central problem of immune incompatibility. However, the feasibility of this approach has yet to be tested, and many issues remain unanswered in this field. We do not know whether the use of somatic cell NT (SCNT) to produce embryonic stem cells, successful in many other species, would find similar success in humans. This is critical because SCNT in monkeys results in a high degree of genetic instability[8]. If successful, whether the age of the donor of the nucleus would become an important factor in terms of the efficacy of SCNT is also not known. This is a serious consideration because a large proportion of patients who might benefit from this technology would be of advanced age. Questions also remain as to whether ES cells can be derived from the oocytes carrying human somatic cell nuclei (the "nt-units"), and whether ES cells derived from these nt-units are capable of somatic differentiation into various cell types.

Mechanisms regulating early embryonic development may be conserved among mammalian species, in that bovine oocyte cytoplasm supports early development of nt-units from many mammalian species including, cow, sheep, pig, monkey, rat[9], and human[2]. In addition, rabbit oocyte cytoplasm has been shown to support the full-term development of nt-units reconstructed with rabbit morula[10] and somatic cells [11] as nuclear donors. In an interspecies NT experiment, rabbit oocytes have been used to repro-

ABBREVIATIONS: NT, nuclear transfer; ntES cells, embryonic stem cells derived from somatic cells by NT; EBs, embryoid bodies; SCNT, somatic cell nuclear transfer; FBS, fetal bovine serum. gram Panda somatic nuclei and have supported development of nt-units to the blastocyst stage[12]. In this study, we tested rabbit oocyte cytoplasm as a means to reprogram human somatic cell nuclei, and demonstrate that the derived cells possess the properties and phenotypes of conventional human ES cells, that they retain a normal karyotype, and that they are capable of multilineage cellular differentiation.

\section{MATERIALS AND METHODS}

\section{Preparation of Recipient Oocytes and Fibroblasts for NT}

Oocytes were collected from oviducts of superovulated New Zealand rabbits $14.5 \mathrm{~h}$ after injection with human chorionic gonadotropin. Surgeries were performed according to the standard protocol issued by the Bioethical Committee of Shanghai Second Medical University. Cumulus cell/oocyte complexes were dissected out from the oviduct and incubated in M2 medium (M5910, Sigma) containing hyaluronidase (300 units/ml, Sigma) for 3-5 min at room temperature $\left(23^{\circ} \mathrm{C}\right.$ to $\left.25^{\circ} \mathrm{C}\right)$. The complexes were then pipetted several times to dissociate cumulus cells from oocytes. Fibroblasts were cultured in $5 \% \mathrm{CO}_{2} / 95 \%$ air $\left(37^{\circ} \mathrm{C}\right)$ in DMEM (GIBCO/BRL), supplemented with $15 \%$ fetal bovine serum (FBS, Hyclone) and 50 units/ $\mathrm{ml}$ penicillin-streptomycin (GIBCO/BRL).

\section{Micromanipulation}

Oocytes were incubated in M2 medium with $7.5 \mathrm{mg} / \mathrm{ml}$ cytochalasin B and Hoechest $33342(5 \mu \mathrm{g} / \mathrm{ml})$ in $5 \% \mathrm{CO}_{2} / 95 \%$ air $\left(38^{\circ} \mathrm{C}\right)$ for $10 \mathrm{~min}$. Enucleation was performed by aspirating the first polar body and M-phase chromosomes with a 15 to $20 \mathrm{~mm}$ outer diameter pipette. The successful enucleation was confirmed by visualizing the karyoplast under UV light[10]. A single donor cell was inserted into the perivitelline space of each enucleated oocyte using the same pipette.

\section{Electrofusion and culture of nt-units}

The fibroblast/oocyte complex was equilibrated at room temperature in a glucose solution ( $0.3 \mathrm{M}$ glucose/ $0.1 \mathrm{mM} \mathrm{MgCl} / 2 / 0.05 \mathrm{mM}$ $\mathrm{CaCl}_{2}$; Sigma) for 5 to $10 \mathrm{~min}$ and placed between two electrodes ( 0 . $5 \mathrm{~mm}$ apart) in a cell fusion chamber of an electrofusion apparatus (Model ECM 830, BTX, San Diego) overlaid with the glucose solution. Electrical pulses $(2.4 \mathrm{kv} / \mathrm{cm}, 60 \mathrm{msec}, 3$ direct current pulses, with $1.0 \mathrm{sec}$ interval) were applied to fuse the fibroblast and oocyte membranes. After electrofusion, nt-units were cultured in $50 \mu \mathrm{l}$ droplets of RD medium supplemented with $15 \%$ FBS under mineral oil (Sigma) at $38^{\circ} \mathrm{C}, 5 \% \mathrm{CO}_{2} / 95 \%$ air.

\section{ntES Cell Culture}

Inner cell masses of blastocysts were manually dissected out and cultured at $37^{\circ} \mathrm{C}, 5 \% \mathrm{CO}_{2} / 95 \%$ air on mitomycin $\mathrm{C}$ (Sigma) treated 
or irradiated (55 Gy) feeder cells prepared from 13.5 day mouse embryos[13]. Culture medium consisted of $80 \%$ DMEM (high glucose formulation, no pyruvate), supplemented with $20 \% \mathrm{FBS} / 1 \mathrm{mM}$ glutamine/0.1 mM 2-mercaptoethanol/1\% non-essential amino acid stock/50 units/ml penicillin-streptomycin. In early stage experiments, leukemia inhibitory factor $(10 \mathrm{ng} / \mathrm{ml})$ was added to the medium. This component was omitted after it was shown that growth of ntES cells was independent of added leukemia inhibitory factor. In some cases, ntES cells were cultured in $80 \%$ Knockout medium (GIBCO/BRL), supplemented with 20\% Knockout Serum Replacement (GIBCO/BRL)/4 ng/ml basic fibroblast growth factor/50 units/ $\mathrm{ml}$ penicillin-streptomycin[13-15]. ntES cells could also be maintained in the medium used for culture of embryonic germ cells[16]. Several days after plating the inner cell mass, a colony of cells with a distinct border develops, composed of mainly undifferentiated stem cells. Subsequent passages of ntES cells were performed using either mechanic dispersion or enzymatic digestion (collagenase IV, 1 $\mathrm{mg} / \mathrm{ml}$ in DMEM medium, $37^{\circ} \mathrm{C}, 5 \% \mathrm{CO}_{2} / 95 \%$ air for 3 to $5 \mathrm{~min}$ ), or the combination of both[13-15]. ntES cells at various passages were cryopreserved and recovered successfully.

\section{Immunohistochemistry}

Monoclonal mouse anti-human neurofilament protein and monoclonal mouse anti-nestin were obtained from Chemicon. Monoclonal antibodies against human a-smooth muscle actin, MyoD1, and polyclonal rabbit antibodies against human myoglobin, human von Willebrand Factor, human a-1-antitrypsin and neuron specific enolase were from DAKO. Polyclonal rabbit anti-Tie-2 and a-fetoprotein were purchased from Santa Cruz Biotechnology. Monoclonal anti-VEGF receptor-2 and b-tubulin were obtained from Sigma. The SSEA-1, SSEA-3, SSEA-4, TRA-1-10, and TRA-1-85 monoclonal antibodies were obtained from Developmental Hybridoma Bank (Iowa city, IA). All antibodies used have been shown to react specifically to the appropriate antigens. The specificity of each of the antibodies is further verified by positive and negative controls included in each experiment. Biotin and FITC labeled secondary antibodies came from Jackson Immunoresearch. Indirect immunohistochemistry was performed with the Vectastain ABC system (Vector Laboratories) using 3, 3'-diaminoanobenzidine as a substrate. Positive staining was brown on a blue background counterstained with hematoxylin. Alkaline phosphatase activity was detected by using nitroblue tetrazolium/5-bromo-4-chloro-3-indolyl phosphate (Roche) as a substrate. To detect fat droplets, cells were fixed in $4 \%$ formaldehyde for $1 \mathrm{~h}$, washed with $70 \%$ ethanol, and incubated in $2 \%$ Oil Red $\mathrm{O}$ for $5 \mathrm{~min}$ at room temperature, followed by additional washes in $70 \%$ ethanol and water.

\section{DNA Genotyping}

Total genomic DNA was extracted by using standard procedures [17] from $1 \times 10^{5}$ fibroblasts or differentiated ntES cells. DNA from both samples was amplified with 14 microsatellite markers (D3s1358, vWA, FGA, Amelogenin, D8s1179, D21s11, D18s51, D5s818, D13s317, D7s820, D16s539, TH01, TPOX, CSF1PO, also see Fig 9 legend) and analyzed on an ABI3100 Genetic Analyzer.
In Situ Hybridization with Digoxigenin-labeled Alu DNA probes

Partially differentiated ntES colonies were manually picked from the culture, fixed in $4 \%$ paraformaldehyde, and embedded in paraffin. Freshly dissected rabbit and mouse ovaries were embedded using the same protocol. DNA-DNA in situ hybridization was as described previously[18-19]. Briefly, tissues were sectioned $5 \mathrm{~mm}$, digested in proteinase $\mathrm{K}(10 \mathrm{mg} / \mathrm{ml})$ at $37^{\circ} \mathrm{C}$ for $15 \mathrm{~min}$, and post-fixed in $0.4 \%$ paraformaldehyde. The probe cocktail was composed of $10 \mu \mathrm{l}$ of 50 $\times$ Denhardt's solution, $50 \mu \mathrm{l}$ dextran sulfate, $100 \mu 120 \times$ SSC, 500 ng digoxigenin-labeled Alu probe in $50 \mu \mathrm{l}$ Tris/EDTA buffer, and distilled water to make a total volume of $250 \mu$ l. Formamide $(250 \mu$ 1) was then added to complete the preparation. Hybridization was carried out in a humidified chamber at $850 \mathrm{C}$ for $10 \mathrm{~min}$, cooled on ice for $5 \mathrm{~min}$, incubated in $42^{\circ} \mathrm{C}$ for $3 \mathrm{~h}$, washed in succession in $2 \times$ SSC, $0.1 \times$ SSC, buffer 1 (0.1 $M$ maleic acid, $0.15 M \mathrm{NaCl}, \mathrm{pH} 7.5)$ and $0.5 \%$ blocking reagent (Roche) in buffer 1 . After incubation with anti-digoxigenin-alkaline phosphatase conjugate (Roche), color was developed by incubation with nitroblue tetrazolium/5-bromo-4chloro-3-indolyl phosphate (Roche).

\section{In Situ Hybridization with Fluorescence-Labeled Probes Specific for Rabbit Mitochondrial DNA}

To generate rabbit mitochondrial DNA probes, the rabbit mitochondrial genome (NC-00913) was compared to the human mitochondrial genome (NC-001807). Three overlapping fragments covering $11713 \mathrm{bp}$ (4883-16596) of the rabbit mitochondrial genome were generated by PCR using the following primer sets: 5' cgcataccctcatcact 3', 5' gggaatatgataattaagge 3' (4883-8036); 5' ctatctattgtttagactcgc 3', 5' cggcgttgtatagttatggt-3' (7708-13676); 5'ttgcaggattcttaatttcc-3', 5' taaatactgtgcggtgat-3' (13159-16596). The fragments were purified by gel electrophoresis, labeled with digoxigenin-11-dUTP (Boehringer Mannheim), ethanol precipitated and dissolved in a buffer composed of $50 \%$ deionized formamide, $2 \times$ SSC, $50 \mathrm{~m} M$ sodium phosphate buffer, $\mathrm{pH} 7.0,10 \%$ dextran sulfate.

nt-units at the blastocyst stage, rabbit parthenogenotes, or pellets of human fibroblasts were embedded in paraffin, sectioned to 4 $\mathrm{mm}$, and place on aminopropyltriethoxysilane (APES)-treated slides. Alternatively, cells were cultured on glass slides, fixed in $4 \%$ formaldehyde.

In situ hybridization was performed as described[20]. Cells fixed on slides were treated with $0.1 \%$ pepsin (Sigma), $\mathrm{pH} 2.0$ at $37^{\circ} \mathrm{C}$ for $2 \mathrm{~min}$. For tissue sections, slides were incubated in $0.2 \mathrm{~N} \mathrm{HCl}$ at room temperature for $10 \mathrm{~min}$ and then with $0.1 \%$ pepsin, $\mathrm{pH} 2.0$ at $37^{\circ} \mathrm{C}$ for $7 \mathrm{~min}$. Samples were post-fixed and dehydrated. After application of the hybridization mix $(6 \mu \mathrm{g} / \mathrm{ml}$ of probes in $2 \times \mathrm{SSC}$, $50 \%$ formamide), slides were incubated in $820 \mathrm{C}$ for $3 \mathrm{~min}$ and then in $37^{\circ} \mathrm{C}$ overnight. After washing, digoxigenin labeled probes were detected with a mouse anti-digoxigenin antibody (Roche) and a Cy3 labeled donkey anti-mouse IgG secondary antibody (Jackson Immunoresearch). In some cases, samples were counterstained with DAPI to highlight nuclei. 


\section{PCR}

One to three ntES colonies were manually removed from the dish and dissociated with $0.25 \%$ trypsin/EDTA (GIBCO) for $30 \mathrm{~min}$, with hyaluronidase $(300 \mathrm{U} / \mathrm{ml})$ at $37^{\circ} \mathrm{C}$ for $30 \mathrm{~min}$, followed by proteinase $\mathrm{K}(400 \mu \mathrm{g} / \mathrm{m}$ in $0.005 \% \mathrm{SDS})$ at $50^{\circ} \mathrm{C}$ for $4 \mathrm{~h}$. DNA samples were prepared from rabbit tissue, $1 \mathrm{ml}$ peripheral human blood or $1 \times 10^{3}$ mouse fibroblast cells using a standard protocol[17]. Primer sets used were as follows: Human chromosome 7 alphoid repeats[21]: 5' C A A G A A G G C T T C A A A G A C C $3^{\prime}$, a n d 5 ' TTCATTGGAATCGCGAATAC 3'; Human keratin 9 gene (Gi: 27484014): 5' GTTTTAGTGCCAGTAGTTTA 3, and 5' GTCCTTGAGATCATCAATAG3'; Mouse mG3PDH gene (Gi: 10048294): 5' ATTCCTTGCCAAGAGGTGAC 3', and 5' CAGCAAGGCAAGGTAGTGTG 3'; Rabbit whey acidic protein gene (WAP, Gi: 23957097): 5' GGTTCCTTTGCAGGCACTTT 3', and 5' CGGCTCCCATCCTTCTCACT 3'. PCR reactions were carried out using following parameters: $94^{\circ} \mathrm{C}$ for $4 \mathrm{~min}, 40$ cycles at $94^{\circ} \mathrm{C}$ for 40 sec, $57^{\circ} \mathrm{C}$ for $30 \mathrm{sec}$, and $72^{\circ} \mathrm{C}$ for $30 \mathrm{sec}$; final extension was at $72^{\circ} \mathrm{C}$ for $10 \mathrm{~min}$.

\section{RESULTS} Reprogramming Human Somatic Nuclei with Rabbit
Ooplasm

Foreskin tissue from two 5-year-old males, one 42year-old male, one 52-year-old male, and facial skin tissue from a 60-year-old female were obtained from discarded tissue after surgery. Fibroblasts were isolated and maintained in DMEM supplemented with $15 \%$ FBS along with antibiotics and allowed to reach confluence. Cells from passage 7 through 20 were used as nuclear donors. Oocytes from New Zealand rabbits were enucleated as described[10]. After fusion, ntunits were allowed to develop to the blastocyst stage at $38^{\circ} \mathrm{C}, 5 \% \mathrm{CO}_{2}$ in $\mathrm{RD}$ medium supplemented with 15\% FBS. Fig 1A and Fig 1B exhibit an nt-unit developing through to the morula stage. Subsequently, outer cells of the morula underwent flattening and the blastocoele became visible (Fig 1C). As culture progressed, the blastocoele cavity expanded and the inner cell mass became obvious at one side of the cavity. In 5-7 days, a proportion of the blastocysts hatched in culture. Fig $1 \mathrm{D}$ shows a blastocyst carrying its inner cell mass as it breaks through the zona pellucida. The identity of ntunits at the blastocyst stage was analyzed by in situ hybridization with probes specific for Alu repeats or rabbit mitochondrial DNA. Sections of nt-units at the blastocyst stage hybridized to both probes, indicating that nt-units contain the primate genome in combination with rabbit mitochondrial DNA (Fig 2).
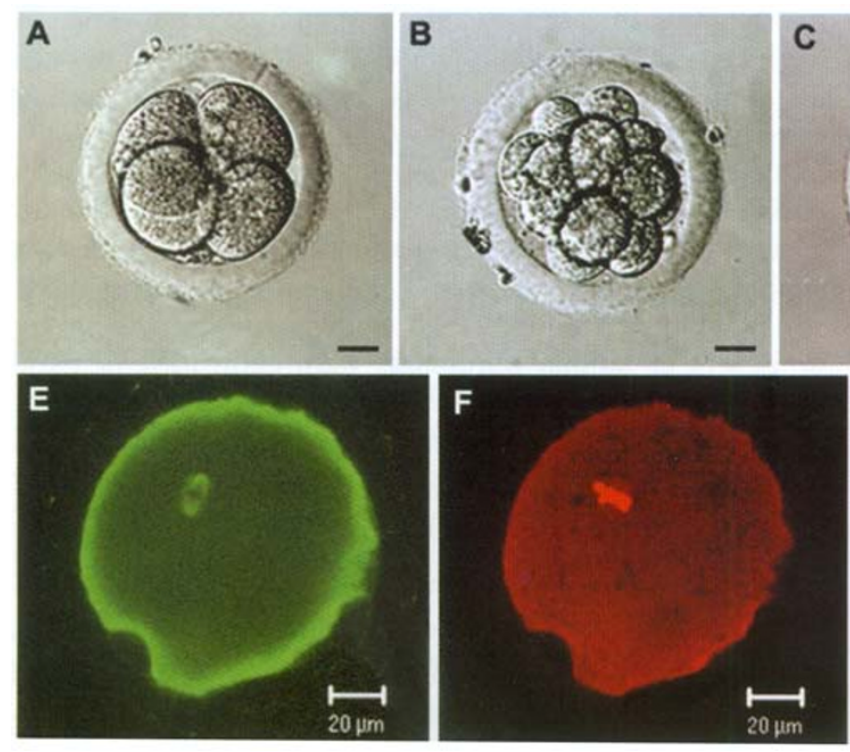
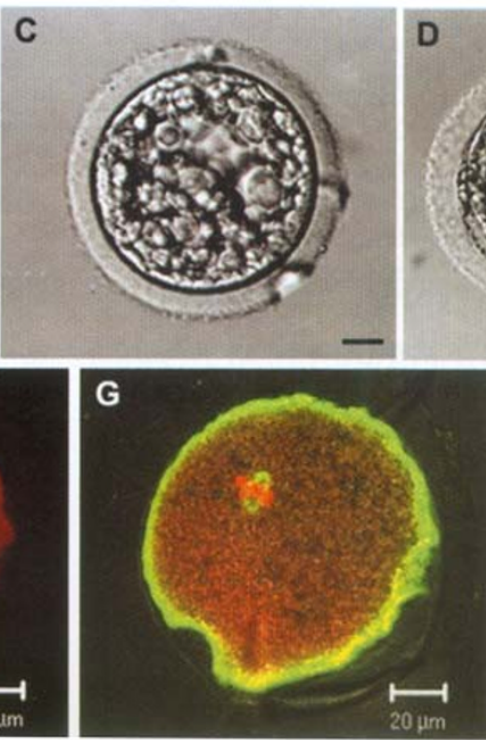
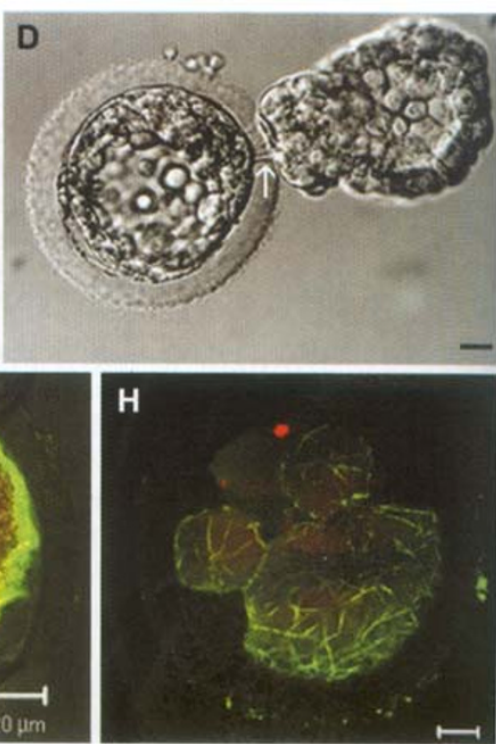

Fig 1. Micrographs of nt-units derived from human somatic cells (A) nt-units derived from fibroblasts of a 42-year old donor at 4-cell stage, 22-24 h after activation; ( B) morula stage, 48-72 h after activation; (C) early blastocyst stage, 5-6 days after activation; and (D) hatching blastocyst stage, 5-7 days after activation. The arrow points to a visible crack in the zona pellucida. (E-G) An nt-unit going through M-phase during the first mitotic division (6 h after activation) with a generally normal spindle structure. ( E) Spindle fibers revealed by an antibody against a-tubulin (green). (F) Chromosomes stained with propidium iodide (red). (G) Overlapping images of (E) and (F). (H) An nt-unit with an unincorporated somatic nucleus. $($ Bars $=20 \mu \mathrm{m})$ 
Tab 1. Somatic cells from donors at different ages formed blastocysts with comparable efficiency.

\begin{tabular}{cccc}
\hline $\begin{array}{c}\text { Age } \\
\text { (year) }\end{array}$ & $\begin{array}{c}\text { No. of fused } \\
\text { nt-units* }\end{array}$ & $\begin{array}{c}\text { No. of stage 2-4 cell } \\
\text { (\% of fused nt-units)** }\end{array}$ & $\begin{array}{c}\text { No. of blastocysts } \\
\text { (\% of fused nt-units) }\end{array}$ \\
\hline 5 & 240 & $52(21.7)$ & $28(11.7)$ \\
42 & 221 & $87(39.4)$ & $23(10.4)$ \\
52 & 300 & $111(37.0)$ & $38(12.7)$ \\
60 & 133 & $71(53.4)$ & $18(13.5)$ \\
\hline
\end{tabular}

*As assessed $0.5 \mathrm{~h}$ after fusion by examination on an inverted microscope.

**Age 5 percentage is significantly different from age 42, 52 and 60; and age 60 percentage is significantly different from age 5, 42 and $52(\mathrm{P}<0.01)$.

These results verify that nt-units at the blastocyst stage originate from human somatic cells reprogrammed by rabbit oocytes, since embryos resulted from either natural mating or parthenogenesis should contain the genomic and mitochondrial DNA of the same species. Thus, rabbit oocytes are capable of at least partially reprogramming human somatic cell nuclei based on development through preimplantation stages.

To examine whether the age of somatic cell donors would influence the effectiveness of SCNT, we conducted NT experiments with fibroblasts from donors at four different ages (5, 42, 52 and 60 years) by using identical electrofusion parameters and culture conditions. Numbers of nt-units that proceeded through sequential developmental stages, including first cleavage, morula, and blastocyst, were recorded and analyzed for each age group. Statistic analysis ( $x^{2}$ test) showed that the number of nt-units at early developmental stages varied significantly among different age groups [e.g. a significant low percentage $(52 / 240,21.7 \%, \mathrm{P}<0.01)$ of nt-units in the age 5 group and a significant high percentage (71/133, 53 . $4 \%, \mathrm{P}<0.01$ ) of nt-units in the age 60 group went through initial division to enter 2- to 4-cell stage]. In addition, a significantly high percentage of 2- to 4-cell stage nt-units developed to blastocysts (28/52, 53.8\%, $\mathrm{P}<0.01)$ in the age 5 group. These results suggest that the rate of nt-units going through early developmental stages may be influenced by the age of the nuclear donor. Overall, however, there was no significant difference in the percentage of blastocysts that developed from fused nt-units in the four age groups $[11.7 \%, 10.4 \%, 12.7 \%$, and $13.5 \%$ for ages $5,42,52$, and 60 years, respectively $(\mathrm{P}>0.05)$; see Tab 1$]$. These data demonstrated that the potential of the human somatic cell nucleus to be reprogrammed may not be diminished by aging, as judged by the ability of ntunits to form blastocysts. It is consistent with results derived from both mouse and bovine cloning experiments where somatic nuclei from adults were successfully reprogrammed[22, 23].

\section{Karyotype of nt-units}

Fig 1E-G shows a spindle structure of a human somatic cell nucleus going through $\mathrm{M}$ phase during the first division in an oocyte, as revealed by staining with propidium iodide and a $\beta$-tubulin specific antibody [24]. The spindle of the nt-unit appeared normal. Under the light microscope, we noted a high proportion of cytoplasmic division and incomplete cell separation of nt-units shortly after NT as illustrated in Fig $1 \mathrm{H}$. This usually resulted from a failure of reprogramming of the somatic cell nucleus because the majority of such units contained a single nucleus, suggesting that the nucleus was not activated (Fig $1 \mathrm{H}$ ). To examine whether the nt-units contained human chromosomes, we performed karyotyping on nt-units at various developmental stages. A total of $174 \mathrm{nt}$-units at 2-cell to blastocyst stages were examined, and 9 metaphases with 46 chromosomes were captured. Gross microscopic examination revealed no obvious abnormalities. Fig 3 displays a metaphase spread showing apparent normal human chromosomes at the 300 band level of resolution. These data demonstrate that nt-units are human in origin.

\section{Isolation and Characterization of ntES Cells}

To isolate embryonic stem cells, inner cell masses were dissected manually from blastocysts and plated 

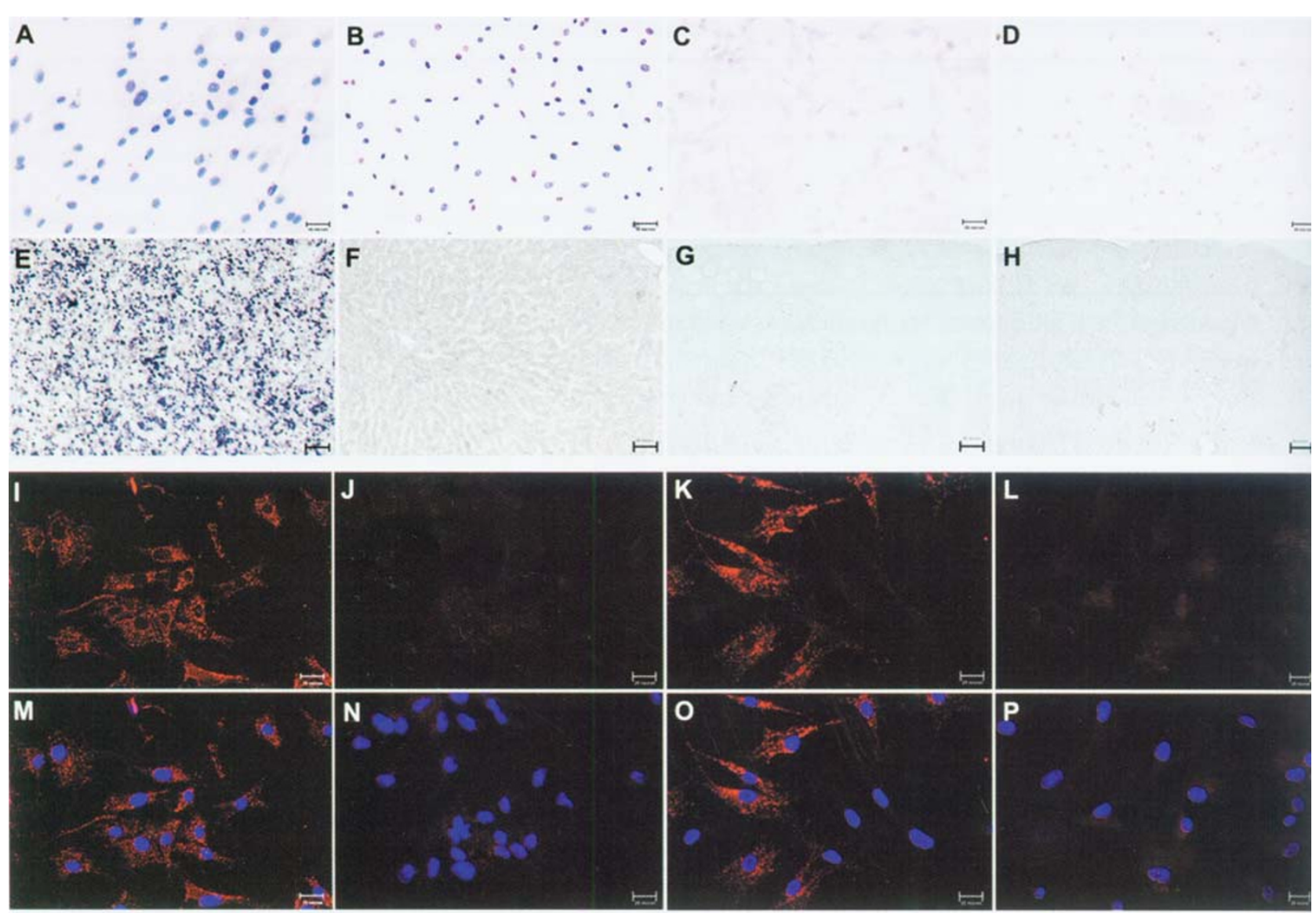

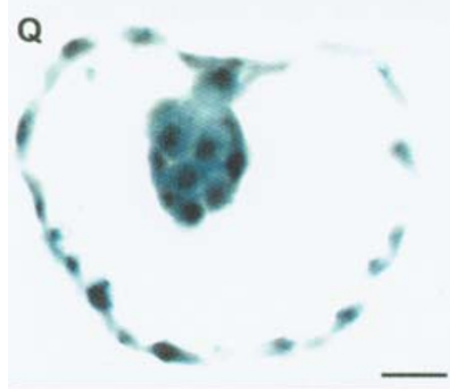

$\mathbf{R}$
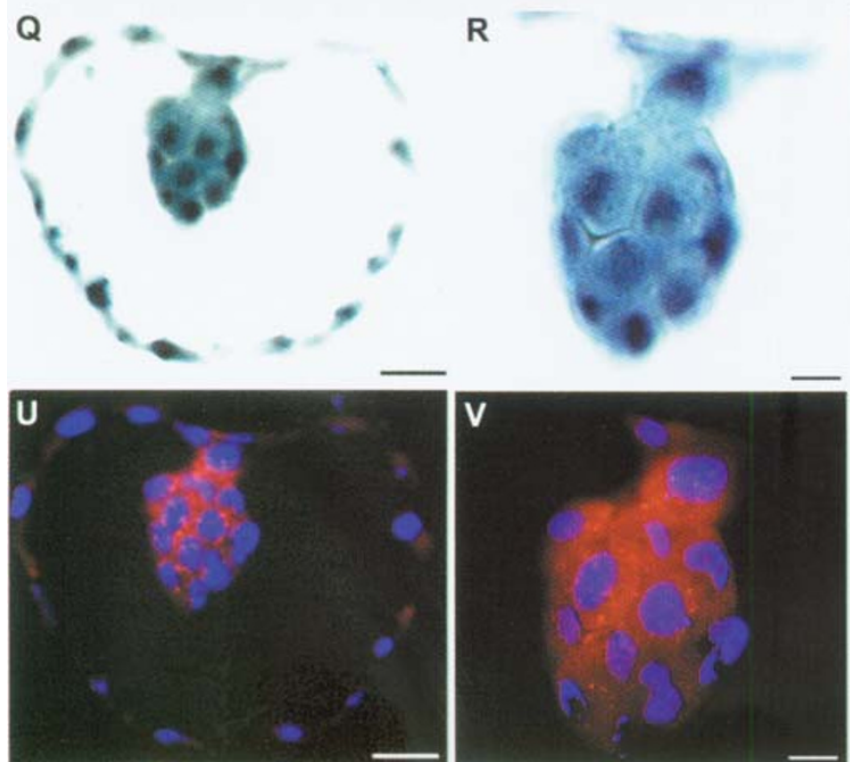
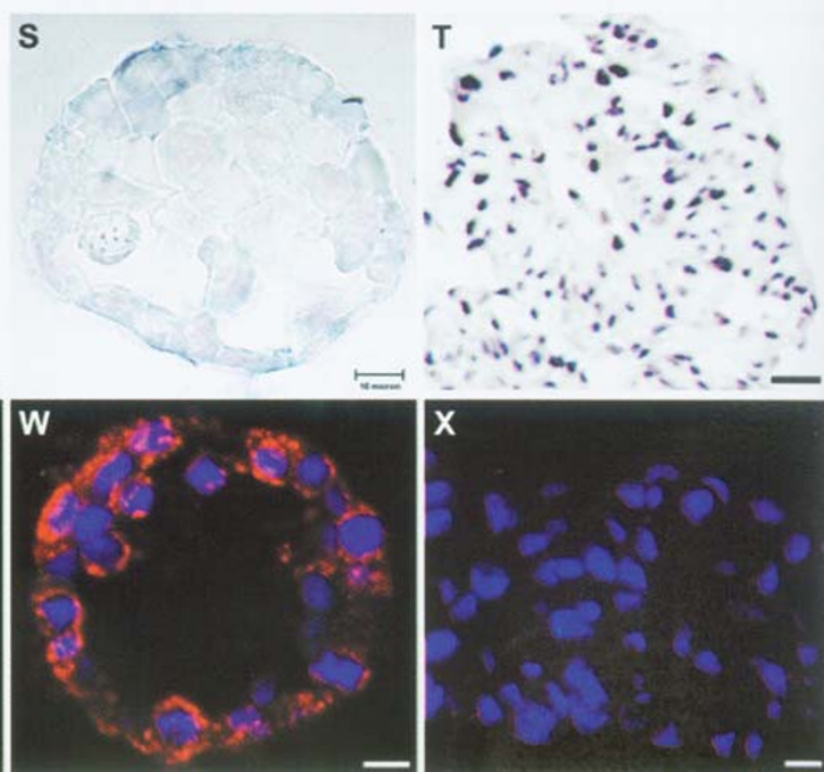

Fig 2. nt-units contain both the primate genome and rabbit mitochondrial DNA (A-H) In situ hybridization experiments showing that Alu probes hybridize specifically to nuclei of primate species. (A) Cultured human, (B) monkey (Rhesus macaque), (C) rabbit and (D) mouse fibroblasts and paraffin sections of $(\mathbf{E})$ human liver, (F) sheep liver, (G) rabbit ovary and (H) mouse ovary were hybridized to Alu probes. Only human and monkey nuclei showed positive signals above the background. (I-P) Results from in situ hybridization demonstrating that probes for rabbit mitochondrial DNA are specie specific. (I, M) Rabbit or (J, N) human fibroblasts or $(\mathbf{K}, \mathbf{O})$ a mixed population of rabbit and human fibroblasts were hybridized to rabbit mitochondrial DNA probes, only the mitochondrial DNA in rabbit fibroblasts showed red fluorescent signals. (L, P) Rabbit fibroblasts were hybridized without probes to serve as negative controls.(Continued on page 257) 


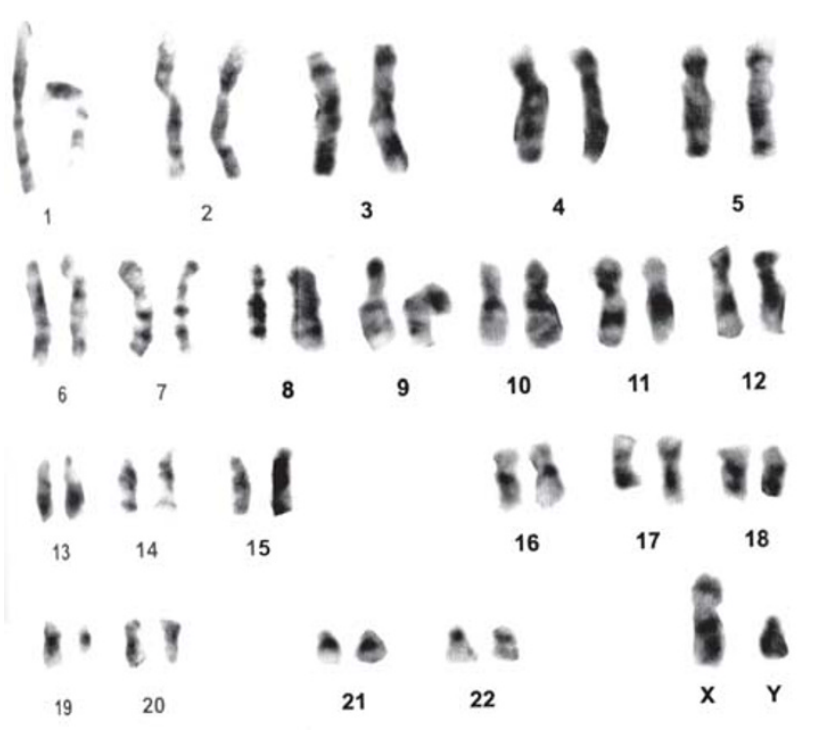

Fig 3. A G-banded karyotype from a 6-cell stage nt-unit The picture shows 22 pairs of autosomes and the two sex chromosomes.

onto feeders of mouse fibroblasts in a culture medium described previously[13]. We have tested three different types of media modified from published work (refs. 13-15, see also Materials and Methods), and all of them were able to support the growth of ntES cells.

Several days after plating of inner cell masses, colonies emerged with the ntES cell morphology of flat colonies containing densely packed cells (Fig 4A-C). These colonies were dissociated and passed on to new feeders. ntES cells expressed a high level of alkaline phosphatase activity (Fig 4D). Marker expression was examined with antibodies against SSEA-1, SSEA-3, SSEA-4, TRA-1-10, and TRA-1-85[13]. ntES cells

(Continued from page 256-Fig 2)

(Q-X) nt-units at the blastocyst stage contain the primate genome and rabbit mitochondrial DNA. (Q, R, U, V) Paraffin sections of nt-units at the blastocyst stage, $(\mathbf{S}, \mathbf{W})$ rabbit parthenogenotes and ( $\mathbf{T}, \mathbf{X})$ human fibroblasts were hybridized to either $(\mathbf{Q}, \mathbf{R}, \mathbf{S}, \mathbf{T})$ Alu probes or $(\mathbf{U}, \mathbf{V}, \mathbf{W}, \mathbf{X})$ rabbit mitochondrial DNA probes. nt-units at the blastocyst stage were stained positively by both $(\mathbf{Q}, \mathbf{R})$ Alu and $(\mathbf{U}, \mathbf{V})$ rabbit mitochondrial DNA probes. (W) Rabbit parthenogenotes stained positively by only rabbit mitochondrial DNA probes, and (T) human fibroblasts by only Alu probes. (Bars in A-H $=50 \mu \mathrm{m}$, in $\mathrm{I}-\mathrm{Q}, \mathrm{T}, \mathrm{U}=25 \mathrm{~mm}$, and in $\mathrm{R}, \mathrm{S}, \mathrm{V}, \mathrm{W}, \mathrm{X}=10 \mu \mathrm{m}$ ) were positive for SSEA-3, SSEA-4, TRA-1-10, and TRA-1-85 (Fig 4E-H) and negative for SSEA-1 just as conventional human ES cells were in previous studies[13, 25]. Thus, with respect to marker expression, human ntES cells showed no difference in comparison with conventional human ES cells.

Over the past two years, we have performed 289 NT experiments excluding the nt-units used for karyotyping. A total of 2418 nt-units have been constructed by using rabbit oocytes fused to human fibroblasts. 1086 (1086/2418, 44.9\%) of these nt-units survived electrofusion, and 158 blastocysts (158/1086, $14.5 \%$ ) were obtained. Approximately $2 / 3$ of these were used to isolate ntES cells. Many continuously renewing ntES cell populations have been isolated from blastocyst stage nt-units. Among these populations, 14 were grown for more than 10 passages and 4 of them for more than 25 passages before cryopreservation (one at 28 , one at 35 and two at 44 passages). In most culture conditions tested so far, these cells grow as tightly packed colonies. Recently, some of the populations were adapted to grow in monolayer on irradiated mouse feeders. Initial analysis of human and rabbit mtDNAs show that both human and rabbit mtDNAs co-exist in ntES cells (data not shown). In-depth analysis of dynamic changes of both mtDNA species in undifferentiated and differentiated ntES cells is necessary. In addition, it is also necessary to test culture conditions to facilitate expansion of ntES cells, to characterize these cell populations regarding their doubling time, the ability to form teratomas, and to search for conditions to grow ntES cells in the absence of mouse feeder cells.

Human ES cell lines express high levels of telomerase activity that seems to be correlated with immortality[13, 26]. Telomerase activity was quantified by use of a TRAP (Telomeric Repeat Amplification Protocol) assay (TeloTAGGG Telomerase PCR ELISA, Roche Diagnostics). Fibroblasts from individuals at three representative ages $(5,42$, and 60 years) were telomerase negative, whereas the ntES cells derived from these fibroblasts by SCNT had high levels of telomerase activity. Thus, the human telomerase activity has been successfully reprogrammed (Fig 5).

The genetic constitution of the ntES cells derived from a 42-year-old donor after 26 passages was examined by karyotyping, revealing a normal complement of human chromosomes (Fig 6). ntES cell colonies were 

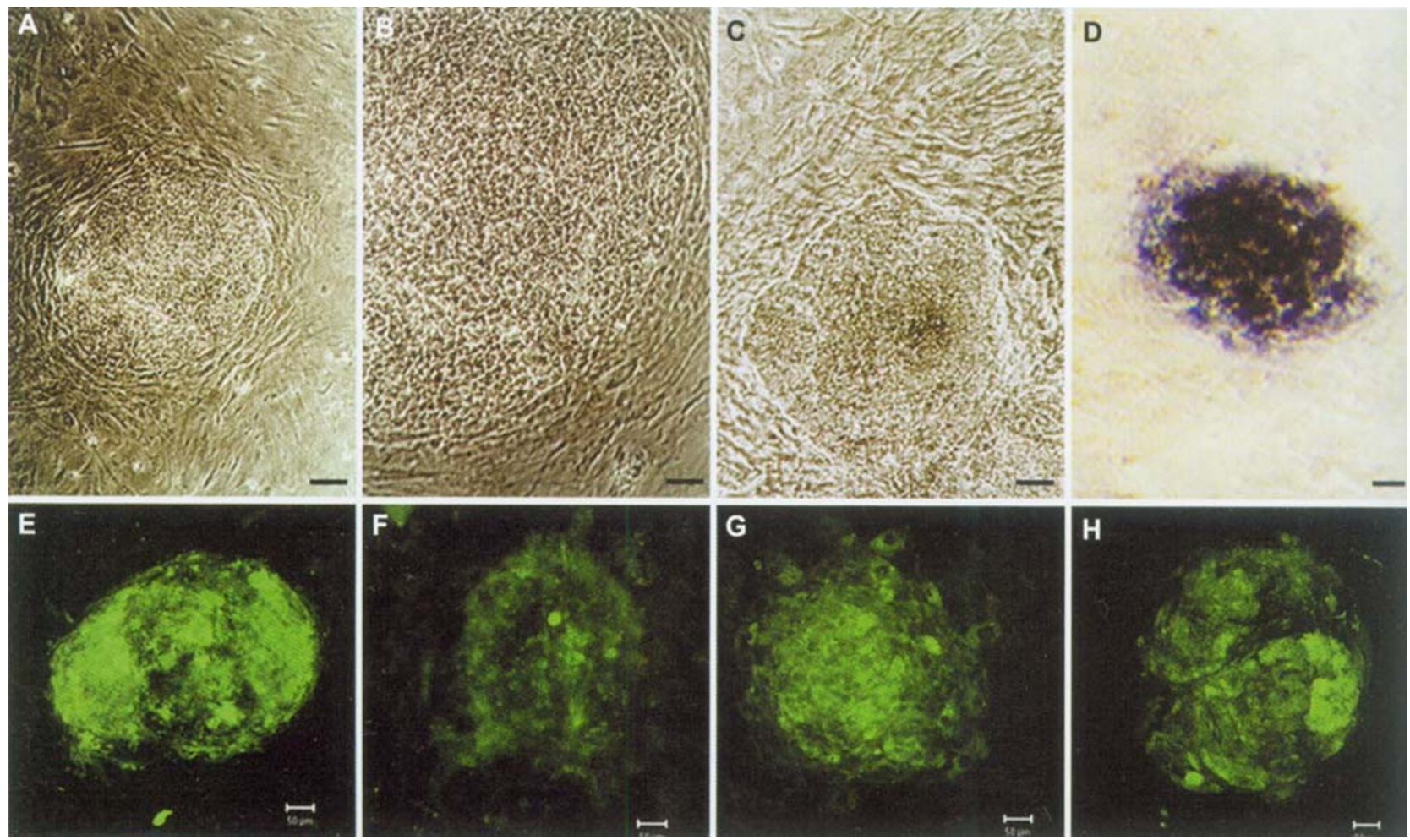

Fig 4. Morphology and marker expression in ntES cells (A) An ntES cell colony derived from a 42-year-old somatic cell donor. (B) Higher magnification of the same colony shown in (A). (C) A colony derived from a 52-year-old somatic cell donor. (D) Alkaline phosphatase activity in ntES cells after 26 passages. The ntES cells express epitopes recognized by antibodies against (E) SSEA3, (F) SSEA-4, (G) TRA-1-10, and (H) TRA-1-85. The ntES cells failed to stain for SSEA-1 (data not shown). (Bars in A and C-H = $50 \mu \mathrm{m} ;$ in $\mathrm{B}=25 \mu \mathrm{m})$

hybridized to probes specific for Alu repeats in the human genome[18, 19]. Alu probes specifically stained nuclei of ntES cells (Fig 7). PCR analysis with primers specific for human chromosome 7 alphoid repeats [21] and to human keratin 9 gene confirmed again that ntES cells are human in origin (Fig 8). To ensure that the ntES cells were in fact encoded by the reprogrammed human nuclei, we performed microsatellite analysis for DNA extracted from the original nuclear donor human fibroblast cells, and from the ntES cells derived from them. Because ntES cells are heavily contaminated with mouse feeder cells, we extracted DNA from differentiated ntES cells that grew in the absence of feeder cells (see below). Microsatellite analysis on the differentiated ntES cells confirmed isogenicity with the original donor fibroblasts (Fig 9). This demonstrated unequivocally that ntES cells are encoded by the genome of the nuclear donor cell.

\section{Somatic Differentiation of ntES Cells}

Conditions that prompted differentiation of conventional human ES or EG cells[13, 16] also induced differentiation of ntES cells.

During passage in a medium containing leukemia inhibitory factor, basic fibroblast growth factor, and forskolin, embryoid bodies (EBs) formed above the plane of the monolayer and appeared under the light microscope as ball-like structures with dark patches (Fig 10A). To induce further differentiation, we transferred EBs to a medium composed of DMEM, $10 \%$ FBS, antibiotics and $5 \times 10^{-7} \mathrm{M}$ retinoic acid (Sigma). Within 1 to 2 days, differentiated cells moved out from the EBs. After a 5-day retinoic acid induction, the culture was transferredto a medium composed of DMEM, 


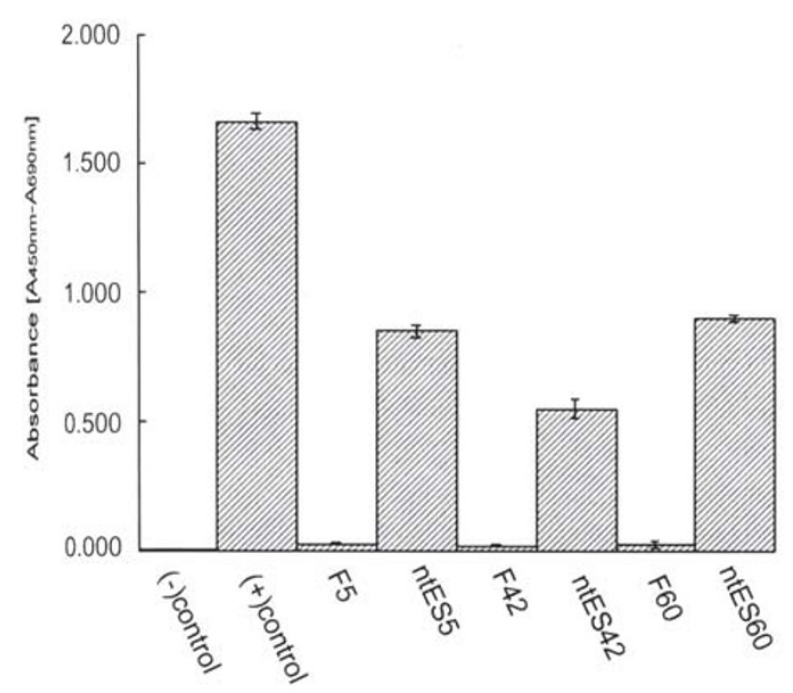

Fig 5. TRAP (telomeric repeat amplification protocol) assay analysis of telomerase activity in ntES cells Cell lysates were prepared from $1 \times 10^{5}$ fibroblasts $(\mathrm{F})$ or ntES cells from individuals at ages 5, 42 and 60 years, respectively. (+) Control, cell extract prepared from immortalized telomerase-expressing human kidney cells (HEK 293 cells); (-) control, heat treated $\left(65^{\circ} \mathrm{C}, 10 \mathrm{~min}\right) \mathrm{HEK} 293$ cells. Columns represent triplicates (means $\pm \mathrm{SD})$.

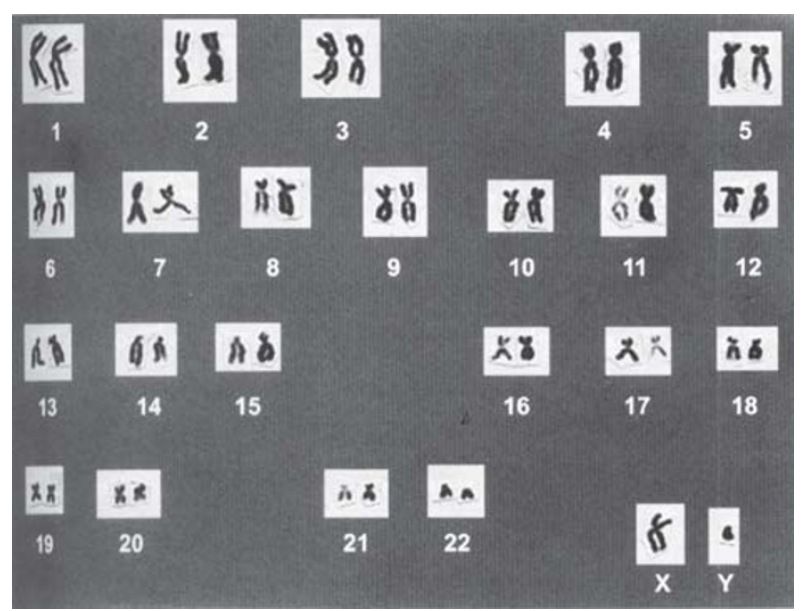

Fig 6. Normal karyotype of ntES cells Metaphase preparation from ntES cells after 4 months of continuous culture. Karyotype: $46, \mathrm{XY}$, normal male.

$10 \%$ FBS; $10 \%$ horse serum (Sigma), $1 \%$ chick embryo extract, and 50 units/ml penicillin-streptomycin. Cells continued growth to a confluent cell sheet, with the EB centrally located within the outgrowth (Fig 10B).

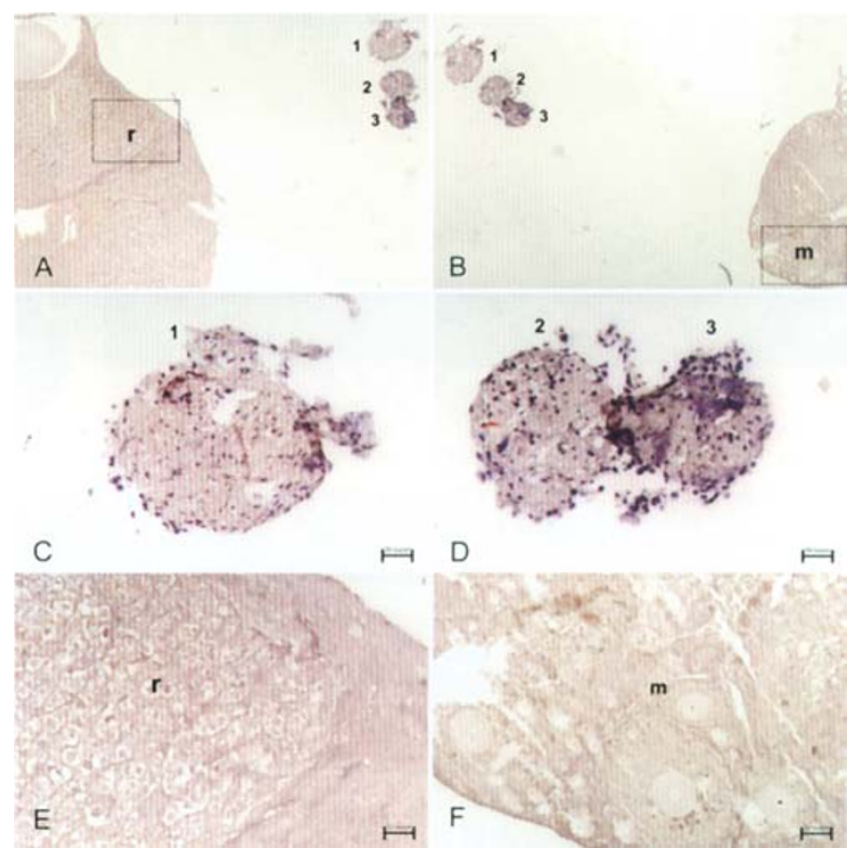

Fig 7. In situ hybridization of ntES cells with Alu probes 㲏 Sections of ntES colonies $(1,2,3)$, (r) rabbit ovary and (m) mouse ovary were hybridized to Alu probes on the same slide. Low magnification pictures show spatial relationship of ntES colonies with (A) rabbit and (B) mouse ovaries. $(\mathbf{C})$ and $(\mathbf{D})$ Higher magnification shows nuclear staining of ntES cells. No signal was detected in $(\mathbf{E})$ rabbit or $(\mathbf{F})$ mouse ovaries. $($ Bars $=$ $50 \mu \mathrm{m})$

Subpopulations of differentiated cells were isolated and grown for limited passages. It was confirmed that these differentiated cells contain primate nuclei that stain positively with Alu probes (Fig 11).

In mouse, EB serves as a unit for initial induction of ES cell differentiation, and a fully developed EB often contains tissues expressing markers of the three germ layers[27, 28]. To examine the inner structure of simple EBs formed by human ntES cells, we prepared $5 \mathrm{~mm}$ sections of frozen EBs and stained them with antibodies against markers of the three germ layers. Inside the ball-like structure shown in Fig 10C$\mathrm{J}$, there were many undifferentiated cells that expressed few cell-type specific markers. In the outer and bottom layers of EBs, we detected expression of nestin (Fig 10C), neuron specific enolase (Fig 10D), [ectoderm]; myoglobin (Fig 10E), a-smooth muscle actin (Fig 10F), VEGF receptor-2 (Fig 10G), Tie-2 (Fig 


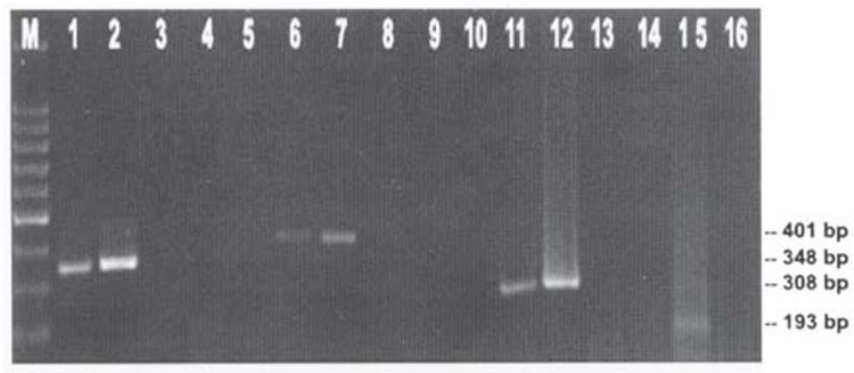

Fig 8. PCR analysis of ntES cells Genomic DNA extracted from ntES colonies (lanes 1, 6, 11, 14), human blood cells (lanes 2, 7 ), rabbit blood cells (lanes $4,9,15$ ) or mouse feeders (lanes 3 , 8,12 ) were amplified by primer sets specific for human chromosome 7 alphoid repeats (lanes 1, 2, 3, 4, 5), human keratin 9 gene (lanes $6,7,8,9,10$ ), mouse G3PDH gene (lanes 11, 12, 13), and rabbit WAP gene (lanes 14, 15, 16), respectively (for primer sequences, see Materials and Methods). Primers specific to human chromosome 7 alphoid repeats detected a 348 bp band in ntES cells (lane 1) and human genomic DNA (lane 2 ) but not in mouse (lane 3) or rabbit (lane 4) genomic DNA. Likewise, primers to the human keratin 9 gene amplified a 401 bp band from ntES cells (lane 6) and human genomic DNA (lane 7) but not from mouse (lane 8) or rabbit (lane 9) genomic DNA. Identities of mouse and rabbit genomic DNA were confirmed with primers specific to the mouse G3PDH gene (308 bp, lane 12) and rabbit WAP gene (193 bp, lane 15). Buffer controls were negative (lane 5, 10, 13, 16). Molecular weight markers are represented by a 100 bp DNA ladder (Takara Biotechnology). Mouse genomic DNA was detected from ntES cell colonies grown on mouse feeder cells (lane11).

10H), [mesoderm]; $\alpha$-fetoprotein (Fig 10I), and $\alpha$-1antitrypsin (Fig 10J), endoderm].

Because outer layers of EBs were positive for a broad range of markers, we stained the outgrowth of EBs with a variety of dyes and antibodies to determine whether these cells were a homogeneous cell population or a mixture of heterogeneous cells. In the outgrowth of EBs, we detected cells with fat droplets that stained positive with the lipid dye Oil Red O (Fig $10 \mathrm{~K}$ and Fig 10L). We also detected muscle cells with an elongated body and cytoplasm with myoglobin expression, a marker for muscle cells (Fig 10M and Fig 10N). Antibodies against a-fetoprotein and a-1antitrypsin, markers of endoderm cell types, recognized groups of cells that grew into clusters with some localized patterns (Fig 100 and Fig 10P). In addition, small groups of cells in the outgrowth expressed markers of endothelial cells, such as VEGF receptor-2, Tie2 and von Willebrand Factor (Fig 10Q-S). There were also sheets of flat cells that expressed markers associated with more than one cell type, for example, nestin (a marker for neuronal precursors, Fig 10T) and myoglobin (a marker for muscle cells, Fig 10U). The expression of MyoD1 was not detected in the outgrowth (Fig 10V). Based on these findings, it was obvious that the cells migrating immediately out of EBs were heterogeneous in marker expression. Expression of multiple cell type specific markers may be a property of certain types of stem cells[16]. The functional aspects of the heterogeneous cell types have not yet been analyzed.

Manipulation of the culture system altered the proportion of cell types in the population. For example, when cultures were switched, after retinoic acid induction, to a neuron-inducing medium composed of
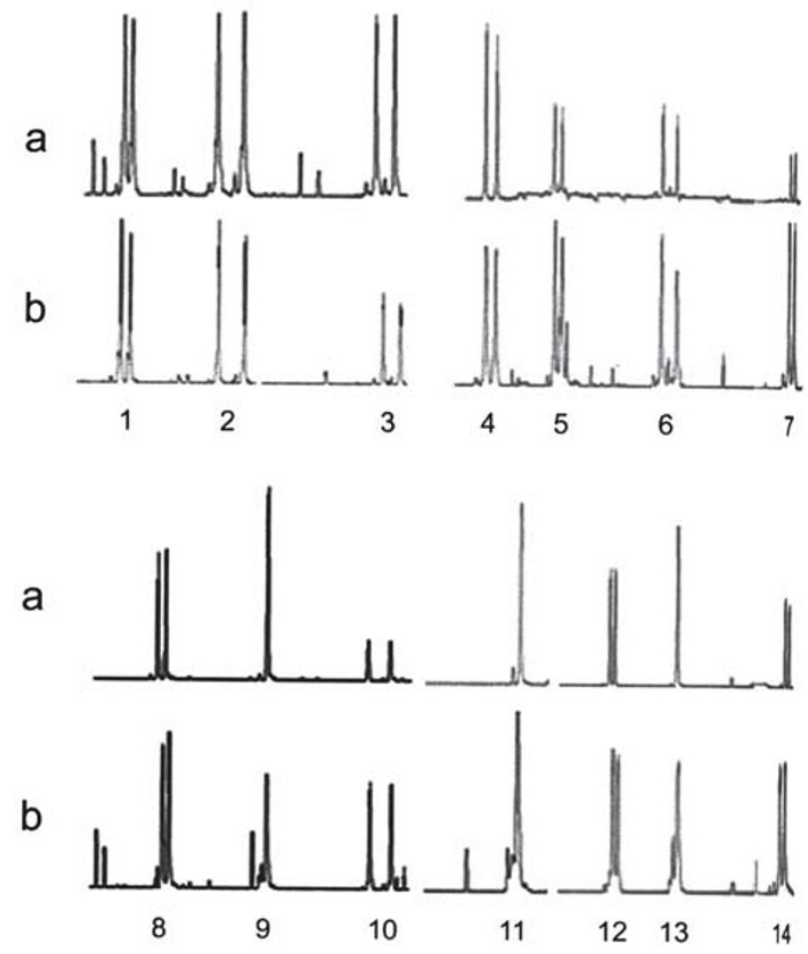

Fig 9. Capillary electrophoresis profiles show isogenicity between nuclear donor cells and ntES cells (a) The 5-year-old nuclear donor fibroblasts. (b) The differentiated ntES cells derived from these fibroblasts. DNA samples were analyzed by multiplex PCR amplification of 14 microsatellite markers: 1, D3s1358; 2, vWA; 3, FGA; 4, Amelogenin; 5, D8s1179; 6, D21s11; 7, D18s51; 8, D5s818; 9, D13s317; 10, D7s820; 11, D16s539; 12, TH01; 13, TPOX; 14, CSF1PO. These were obtained from Profiler-Plus using a Co-filer kit (ABI Biosystem). Genotypes were determined by capillary electrophoresis on an ABI 3100 Genetic Analyzer and analyzed by Genescan and Genotyper software. 


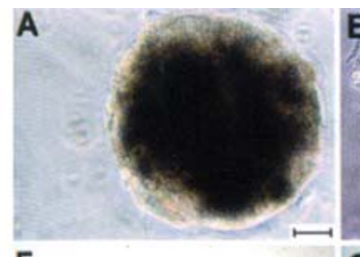

F
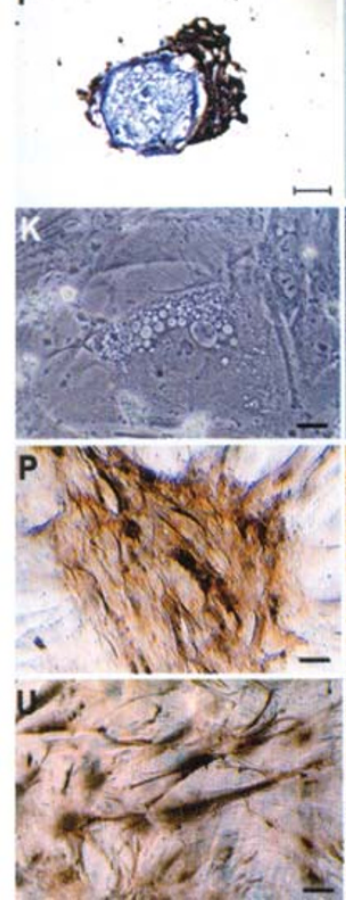
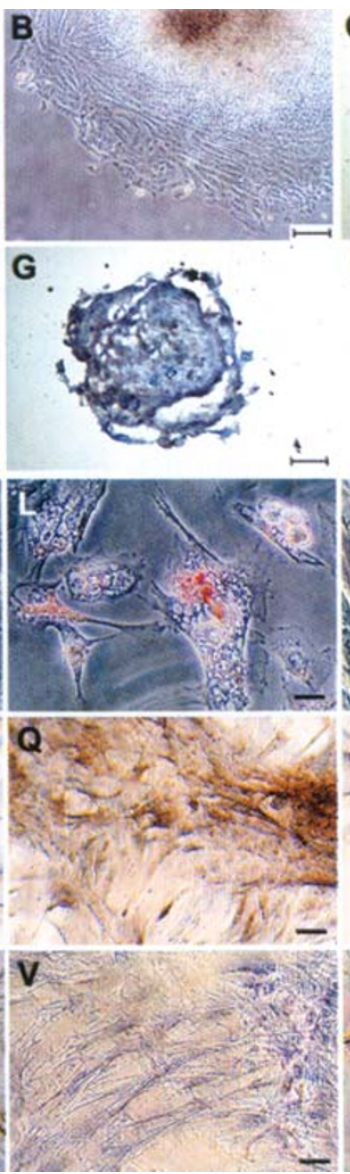

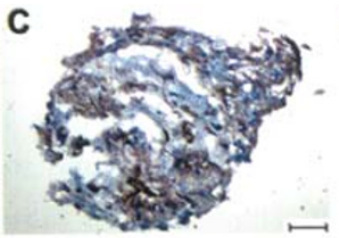

H

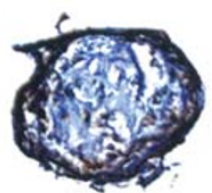

D

I
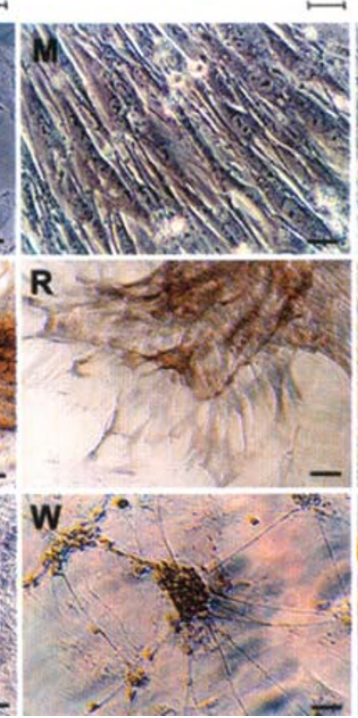
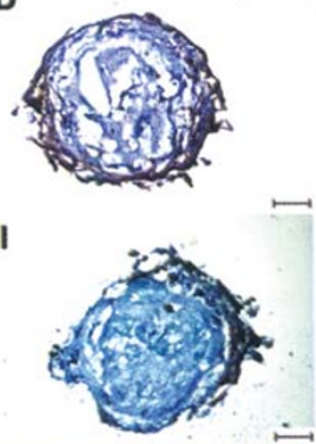

E
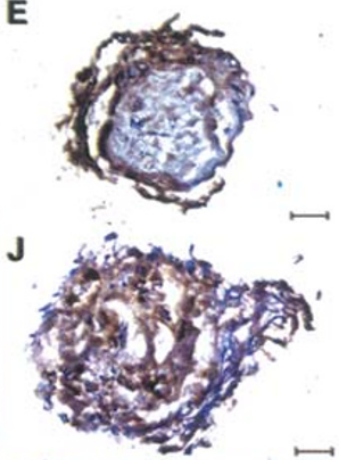

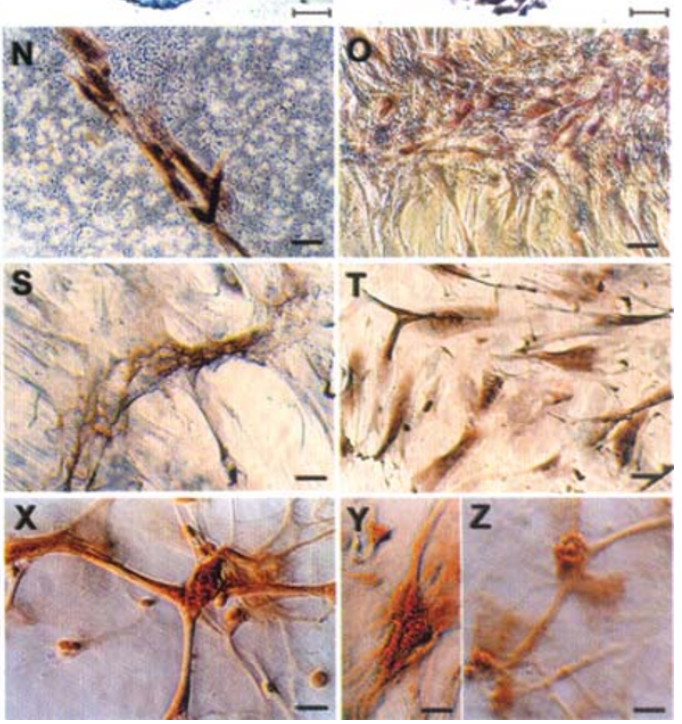

Fig 10. Somatic differentiation of ntES cells 战 (A) An EB. (B) Outgrowth from an EB. (C-J) Cryostat sections of EBs stained by antibodies against $(\mathbf{C})$ nestin, $(\mathbf{D})$ neuron specific enolase, (E) myoglobin, (F) a-smooth muscle actin, (G) VEGF receptor-2, (H) Tie2, (I) a-fetoprotein, (J) a-1-antitrypsin. ( K-N) Multilineage differentiation of the ntES cells that have grown out from an EB. (K) and (L) Cells containing fat droplets stained by Oil Red O. (M) Muscle cells in parallel alignment. (N) Muscle fibers stained by

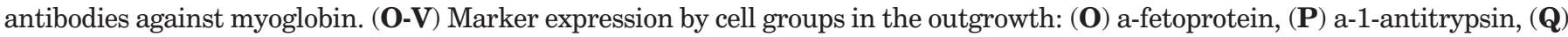
VEGF recptor-2, (R) Tie-2, (S) von Willebrand Factor, (T) nestin, (U) myoglobin, and (V) MyoD1. (W-Z) Neuron formation. (W) Neuronal network formed by ntES cells. Neurons stained by $(\mathbf{X})$ neurofilament-H, $(\mathbf{Y})$ neuron specific enolase, and $(\mathbf{Z})$ nestin, respectively. Sections displayed are from multiple EBs formed by ntES cells derived from the 5-year-old fibroblasts. (Bars in A$\mathrm{J}=50 \mu \mathrm{m}$, in $\mathrm{K}-\mathrm{W}=25 \mu \mathrm{m}$, and in $\mathrm{X}-\mathrm{Z}=12.5 \mu \mathrm{m})$

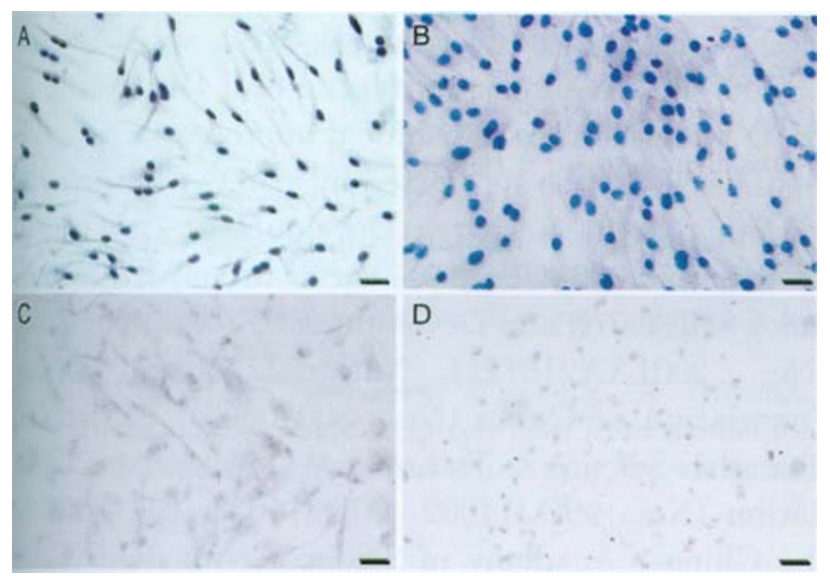

Fig 11. Cells differentiated from ntES cells contain a primate genome as demonstrated by in situ hybridization with Alu probes (A) Differentiated ntES cells, $(\mathbf{B})$ human fibroblasts, $(\mathbf{C})$ rabbit fibroblasts and (D) mouse fibroblasts were hybridized to Alu probes as described in fig2 legend. (Bar $=50 \mu \mathrm{m}$ ) 
DMEM, 1\% ITS (GIBCO), and 50 units/ml penicillinstreptomycin, the EBs gave rise to neurons (Fig 10W). Neuronal cells derived from ntES cells were positive for neurofilament-H (Fig 10X) and neuron-specific enolase (Fig 10Y). Nestin, strongly expressed in precursor cells, was weakly expressed in mature neurons (Fig 10Z).

\section{DISCUSSION}

In this study, we demonstrate that human somatic cell nuclei can be reprogrammed to develop to the balstocyst stage at least; reprogramming of human somatic nuclei can be achieved through using nonhuman mammalian oocytes; ntES cells can be isolated from nt-units at the blastocyst stage and they are capable of self-renewal and differentiate into cells of all three germ layers.

ntES cells possess many properties of human ES cells, including the origin from ICM, expression of surface markers, special growth requirements, such as dependence in feeders and independence in leukemia inhibitory factors, capabilities of self-renewal, formation of embryoid body and differentiation into cells of all three germ layers. Data present in this paper therefore show that ntES cells meet majority, but not yet all of the criteria set recently for human ES cells[29]. Further experiments are necessary to prove that ntES cells have the same developmental potential as conventional human ES cells.

The isolation of human embryonic stem cells, and the successful directed differentiation of these cells [13-15, 30] may result in an ability to correct various diseases through cellular transplantation. However, the use of human ES cell lines for transplantation will face immunological challenges as seen with the transplantation of organs. Here, we show that human embryonic stem cells, originating from a somatic cell nucleus, but without the use of a human egg, are capable of developing into cell types of all 3 germ layers. Therefore, nuclear transplantation appears to offer an opportunity to form stem cells in vitro from any given human patient. Although the fate of the mitochondria (rabbit/human) in these human ES cells remains unresolved, it is possible that these cells will be recognized as 'self' when transplanted back into the same patient.

Aside from its implication in medicine, reprogramming human somatic nuclei also provides a tool to study events occurring during the earliest stages of development. Molecular mechanisms governing fundamental biological phenomena, such as pluripotency, reprogramming, differentiation, and imprinting are currently unknown. Understanding those events may in turn bring new developments to improve human health.

\section{ETHICAL REGULATIONS}

All experiments were performed in accordance with the guidelines on human stem cell research (draft) issued by the Committee on Bioethics, Chinese National Human Genome Center (Southern Headquarter), and endorsed by Shanghai Municipal Government. The guidelines forbid human reproductive cloning, but allow research on SCNT in humans for the purpose of deriving pluripotent stem cells from somatic cells. The guidelines permit utilization of animal oocytes in human SCNT for research purposes, but prohibit application of these cells for human use. The guidelines prohibit combination of animal gametes with human gametes, development of nt-units beyond a 14-day period, and the introduction of nt-units into the uterus of any species. The guidelines also require that tissues used for SCNT experiments must be obtained with informed consent from donors.

\section{ACKNOWLEDGEMENT}

We are grateful to Drs. M Brown, JL Goldstein, DL Garbers and $\mathrm{R}$ Hammer for critical reading of the manuscript. We thank You Ming ZHU, Zheng Ya TANG, Wen Jun DING, Chao PENG, Min Jie NI, Yang WANG for their excellent technical support and Dr. Lan Dian HU for her assistance in DNA microsatellite analysis. Also, we thank Dr. Li Jun ZHANG for karyotyping and Dr. Qiang Su GUO for assistance in confocal microscopic analysis.

This work was supported by grants from the Major State Basic Research Development Program of China. (No. 001CB5099), the National High Technology Research and Development Program of China (No. 2001AA216121), National Natural Science Foundation of China (No. 30040003), Projects of Shanghai Science \& Technology Development Foundation (No. 99DJ14002, 00DJ14033, 01DJ14003), the Chinese Academy of Sciences (No. KSCX-2-3-08), Shanghai Municipal Education Commission and by Shanghai 
Second Medical University.

\section{REFERENCES}

1. Solter D, J Gearhart. Putting stem cells to work. Science 1999; 283:1468-70.

2. Lanza RP, JB Cibelli, MD West. Human therapeutic cloning. Nature Med 1999; 5:975-7.

3. Colman A, A Kind. Therapeutic cloning: concepts and practicalities. Trends Biotechnol 2000; 18:192-6.

4. Cibelli JB, SL Stice, PJ Golueke, et al. Transgenic bovine chimeric offspring produced from somatic cell-derived stemlike cells. Nature Biotechnol 1998; 16:642-6.

5. Munsie MJ, AE Michalska, CM O払rien, AO Trounson, MF Pera, PS Mountford. Isolation of pluripotent embryonic stem cells from reprogrammed adult mouse somatic cell nuclei. Curr Biol 2000; 10:989-92.

6. Kawase E, Y Yamazaki, T Yagi, R Yanagimachi, RA Pedersen. Mouse embryonic stem (ES) cell lines established from neuronal cell-derived cloned blastocysts. Genesis 2000; 28:15663.

7. Wakayama T, V Tabar, I Rodriguez, AC Perry, L Studer, P Mombaerts. Differentiation of embryonic stem cell lines generated from adult somatic cells by nuclear transfer. Science 2001; 292:740-3.

8. Simerly C, T Cominko, C Navara, et al. Molecular correlates of primate nuclear transfer failures. Science 2003; 300:297.

9. Dominko T, M Mitalipova, B Haley, et al. Bovine oocyte cytoplasm supports development of embryos produced by nuclear transfer of somatic cell nuclei from various mammalian species. Biol Reprod 1999; 60:1496-1502.

10. Yang X, S Jiang, A Kovás, RH Foote. Nuclear totipotency of cultured rabbit morulae to support full-term development following nuclear transfer. Biol Reprod 1992; 47:636-43.

11. Chesn? P, PG Adenot, C Viglietta, M Baratte, L Boulanger, JP Renard. Cloned rabbits produced by nuclear transfer from adult somatic cells. Nature Biotechnology 2002; 20: 366-9.

12. Chen DY, QY Sun, JL Liu, et al. Dedifferentiation of giant panda (Ailuropoda melanoleuca) somatic nuclei in rabbit ooplasm and early development of the reconstructed egg. Science in China (Series C) 1999; 29:24-330.

13. Thomson JA, J Itskovitz-Eldor, SS Shapiro, et al. Embryonic stem cell lines derived from human blastocysts. Science 1998; 282:1145-7.

14. Itskovitz-Eldor J, M Schuldiner, D Karsenti, et al. Differentiation of human embryonic stem cells into embryoid bodies compromising the three embryonic germ layers. Mol Med 2000; 6:88-95.

15. Reubinoff BE, MF Pera, CY Fong, A Trounson, A Bongso. Embryonic stem cell lines from human blastocysts: somatic differentiation in vitro. Nature Biotechnol 2000; 18:399404.

16. Shamblott MJ, J Axelman, JW Littlefield, et al. Human embryonic germ cell derivatives express a broad range of developmentally distinct markers and proliferate extensively in vitro. Proc Natl Acad Sci USA 2001; 98:113-8.

17. Sambrook J, DW Russell. Molecular Cloning: a Laboratory Manual. (Cold Spring Harbor Laboratory Press, Cold Spring Harbor, New York). 2001.

18. Brüstle O, K Choudhary, K Karram, et al. Chimeric brains generated by intraventricular transplantation of fetal human brain cells into embryonic rats. Nat Biotechnol 1998; 16:1040-4.

19. Rubin CM, CM Houck, PL Deininger, T Friedmann, CW Schmid. Partial nucleotide sequence of the 300-nucleotide interspersed repeated human DNA sequences. Nature 1980; 284:372-4.

20. Van de Corput MP, JM van den Ouweland, RW Dirks, LM Hart, GJ Bruining, JA Maassen, AK Raap. Detection of mitochondrial DNA deletions in human skin fibroblasts of patients with Pearson抯 syndrome by two-color fluorescence in situ hybridization. J Histochem Cytochem 1997; 45:5561.

21. Dunham I, C Lengauer, T Cremer, T Featherstone. Rapid generation of chromosome-specific alphoid DNA probes using the polymerase chain reaction. Hum Genet 1992; 88: 457-62.

22. Wakayama T, R Yanagimachi. Mouse cloning with nucleus donor cells of different age and type. Mol Reprod Dev 2001; 58:376-83.

23. Kubota C, H Yamakuchi, J Todoroki, et al. Six cloned calves produced from adult fibroblast cells after long-term culture. Proc Natl Acad Sci USA 2000; 97:990-5.

24. Wang WH, L Meng, RJ Hackett, R Odenbourg, DL Keefe. The spindle observation and its relationship with fertilization after intracytoplasmic sperm injection in living human oocytes. Fertility and Sterility 2001; 75:348-53.

25. Pera MF, B Reubinoff, A Trounson. Human embryonic stem cells. J Cell Sci 2000; 113:5-10.

26. Kim NW, MA Piatyszek, KR Prowse, et al. Specific association of human telomerase activity with immortal cells and cancer. Science 1994; 266:2011-5.

27. Doetschman TC, H Eistetter, M Katz, W Schmidt, R Kemler. The in vitro development of blastocyst-derived embryonic stem cell lines: formation of visceral yolk sac, blood islands and myocardium. J Embryol Exp Morph 1985; 87:27-45.

28. Rathjen PD, J Lake, LM Whyatt, MD Bettess, J Rathjen. Properties and uses of embryonic stem cells: prospects for application to human biology and gene therapy. Reprod Fertil Dev 1998; 10:31-47.

29. Brivanlou AH, FH Gage, R Jaenisch, T Jessell, D Melton, J Rossant. Setting standards for human embryonic stem cells. Science 2003; 300:913-6.

30. Odorico JS, DS Kaufman, JA Thomson. Multilineage differentiation from human embryonic stem cell lines. Stem Cells 2001; 19:193-204. 